This Section of Epidemiology and Psychiatric Sciences appears in each issue of the Journal to stress the relevance of epidemiology for behavioural neurosciences, reporting the results of studies that explore the use of an epidemiological approach to provide a better understanding of the neural basis of major psychiatric disorders and, in turn, the utilisation of the behavioural neurosciences for promoting innovative epidemiological research.

The ultimate aim is to help the translation of most relevant research findings into every-day clinical practice. These contributions are written in house by the journal's editorial team or commissioned by the Section Editor (no more than 1000 words, short unstructured abstract, four key-words, one Table or Figure and up to ten references).

Paolo Brambilla, Section Editor

\title{
Basal ganglia and restricted and repetitive behaviours in Autism Spectrum Disorders: current status and future perspectives
}

\author{
S. Calderoni ${ }^{1}$, M. Bellani ${ }^{2 *}$, A. Y. Hardan ${ }^{3}$, F. Muratori ${ }^{1,4}$ and P. Brambilla ${ }^{5,6}$ \\ ${ }^{1}$ IRCCS Stella Maris Foundation, Pisa, Italy \\ ${ }^{2}$ Department of Public Health and Community Medicine, Section of Psychiatry and Section of Clinical Psychology, Inter-University Center for \\ Behavioural Neurosciences (ICBN), University of Verona, Verona, Italy \\ ${ }^{3}$ Department of Psychiatry and Behavioral Sciences, Stanford University, Stanford, CA, USA \\ ${ }^{4}$ Department of Clinical and Experimental Medicine, University of Pisa, Italy \\ ${ }^{5}$ Department of Experimental \& Clinical Medicine, Inter-University Center for Behavioural Neurosciences (ICBN), University of Udine, Udine, Italy \\ ${ }^{6}$ IRCCS “E. Medea" Scientific Institute, UDGEE, Udine, Italy
}

This editorial offers a concise overview of the recent structural magnetic resonance imaging studies that evaluate the basal ganglia (BG) volumes in autism spectrum disorders (ASD). The putative relationship between the repetitive or stereotyped behaviours of ASD and BG volumes is also explored, with a focus on possible translational approaches.

Received 12 November 2013; Revised 3 February 2014; Accepted 4 February 2014; First published online 12 May 2014

Key words: Autism spectrum disorders (ASD), basal ganglia, structural magnetic resonance imaging (sMRI), volumes.

Under the umbrella category of autism spectrum disorder (ASD) are included neurodevelopmental conditions with a high genetic and phenotypic heterogeneity, but shared by a symptom dyad: (1) deficits in social communication and interactions; and (2) repetitive patterns of behaviour, interests and activities (Diagnostic and Statistical Manual of Mental Disorders, DSM-5; American Psychiatric Association, 2013). The

* Address for correspondence: Dr M. Bellani, Department of Public Health and Community Medicine, Section of Psychiatry and Section of Clinical Psychology, University of Verona, Piazzale L.A. Scuro 10, 37134 Verona, Italy.

(Email: marcella.bellani@univr.it) modifications of the diagnostic criteria included in the current version of DSM have enhanced the role of the second domain: in fact, the restricted and repetitive behaviours (RRB), once considered non-ASD specific and subordinate to the socio-communication deficit, are now required for an ASD diagnosis.

Recent ASD research attempted to investigate whether the social communication and RRB dimensions are correlated with distinct endophenotypes and genotypes. In fact, a number of family studies in ASD have shown that genes controlling RRB are independent of genes controlling social or communication impairments (Mandy \& Skuse, 2008). Similarly, among the neuroanatomical correlates of ASD 
Table 1. Summary of studies published between 2005-2013 investigating basal ganglia volumetry in patients with autism spectrum disorders (ASD) compared with control subjects

\begin{tabular}{|c|c|c|c|c|c|c|}
\hline Study & Subjects & Age in years (SD) & Full-scale IQ & MRI methods & $\begin{array}{l}\text { Significant BG findings in ASD relative } \\
\text { to controls }\end{array}$ & Brain-behaviour correlation in ASD \\
\hline $\begin{array}{l}\text { Hollander } \\
\text { et al. (2005) }\end{array}$ & $\begin{array}{r}17 \mathrm{ASD} \\
17 \mathrm{TD}\end{array}$ & $\begin{array}{l}28.4(11.3) \\
29.4(9.1)\end{array}$ & $\begin{array}{l}97.1(25.4) \\
\quad 111.5(14.2)\end{array}$ & $\begin{array}{l}1.5 \mathrm{~T} \text {; ROI manual } \\
\text { tracing }\end{array}$ & $\begin{array}{l}\text { Enlargement in right caudate and } \\
\text { putamen volumes (TBV as covariate) }\end{array}$ & $\begin{array}{l}\text { Positive correlation between RRB assessed through } \\
\text { the ADI-R and right caudate volume }\end{array}$ \\
\hline $\begin{array}{l}\text { Haznedar } \\
\text { et al. (2006) }\end{array}$ & $\begin{array}{r}17 \mathrm{ASD} \\
17 \mathrm{TD}\end{array}$ & $\begin{array}{r}27.7(11.3) \\
28.8(9.4)\end{array}$ & $\begin{array}{l}97.1(25.3) \\
\quad 111.5(14.3)\end{array}$ & $\begin{array}{l}1.5 \mathrm{~T} \text {; ROI manual } \\
\text { tracing }\end{array}$ & $\begin{array}{l}\text { Enlargement in right caudate volume } \\
\text { (TBV as covariate) }\end{array}$ & n.r. \\
\hline $\begin{array}{l}\text { Rojas et al. } \\
\text { (2006) }\end{array}$ & $\begin{array}{l}24 \mathrm{AD} \\
23 \mathrm{TD}\end{array}$ & $\begin{array}{l}20.8(10.6) \\
21.4(10.9)\end{array}$ & $\begin{array}{l}94,7(20,6) \\
\quad 118,7(11,2)\end{array}$ & $1.5 \mathrm{~T} ; \mathrm{VBM}$ & $\begin{array}{l}\text { Enlargement in caudate volumes } \\
\text { (TGMV as covariate) }\end{array}$ & $\begin{array}{l}\text { Positive correlation between RRB assessed through } \\
\text { the ADI-R and caudate volumes }\end{array}$ \\
\hline $\begin{array}{l}\text { Voelbel et al. } \\
\text { (2006) }\end{array}$ & $\begin{array}{r}38 \text { ASD } \\
12 \mathrm{BD} \\
13 \mathrm{TD}\end{array}$ & $\begin{array}{r}10.2(1.9) \\
10.1(1.3) \\
10.7(1.5)\end{array}$ & $\begin{array}{l}99.4(16.1) \\
102.2(12.2) \\
115.1(9.4)\end{array}$ & $\begin{array}{l}1.5 \mathrm{~T} \text {; ROI manual } \\
\text { tracing }\end{array}$ & $\begin{array}{l}\text { Enlargement in caudate volumes (TBV } \\
\text { as covariate) }\end{array}$ & $\begin{array}{l}\text { Negative correlation between executive functions } \\
\text { assessed through WCST and caudate volumes }\end{array}$ \\
\hline $\begin{array}{l}\text { Langen et al. } \\
\qquad(2007)\end{array}$ & $\begin{array}{l}\text { (a) } 21 \text { HFA } \\
21 \text { TD } \\
\text { (b) } 21 \text { HFA } \\
21 \text { TD }\end{array}$ & $\begin{array}{l}11.1(2.2) \\
10.4(1.8) \\
20.1(3.1) \\
20.3(2.2)\end{array}$ & $\begin{array}{r}106,5(13,7) \\
107.6(13.4) \\
114,9(19,2) \\
112.6(10.2)\end{array}$ & $\begin{array}{l}1.5 \mathrm{~T} \text {; ROI manual } \\
\text { tracing }\end{array}$ & $\begin{array}{l}\text { Enlargement in caudate volumes for (a) } \\
\text { and (b) samples (TBV as covariate) } \\
\text { and in putamen volumes for } \\
\text { sample (a) }\end{array}$ & $\begin{array}{l}\text { No significant correlations between RRB assessed } \\
\text { through the ADI-R and BG structures }\end{array}$ \\
\hline $\begin{array}{l}\text { Langen et al. } \\
\qquad(2009)\end{array}$ & $\begin{array}{l}99 \text { HFA } \\
89 \text { TD }\end{array}$ & $\begin{aligned} & 12.9(4.4) \\
& 12.4(4.8)\end{aligned}$ & $\begin{array}{l}107.6(13.6) \\
109.9(12.8)\end{array}$ & $\begin{array}{l}\text { 1.5; ROI manual } \\
\text { tracing and VBM }\end{array}$ & $\begin{array}{l}\text { Enlargement in caudate volumes } \\
\text { (specifically in head of the caudate } \\
\text { nucleus) (TBV as covariate) }\end{array}$ & $\begin{array}{l}\text { Negative correlation between insistence on } \\
\text { sameness cluster of ADI-R and caudate volumes, } \\
\text { particularly evident in the younger age group }\end{array}$ \\
\hline $\begin{array}{l}\text { Estes et al. } \\
\qquad(2011)\end{array}$ & $\begin{array}{l}45 \text { ASD } \\
14 \mathrm{DD} \\
25 \mathrm{TD}\end{array}$ & $\begin{array}{l}47.4 \text { (4.2) months } \\
47.5 \text { (5.6) months } \\
47.4 \text { (6.9) months }\end{array}$ & $\begin{array}{l}59.1(20.6) \\
56.9(14.4) \\
\text { Evaluated, } \\
\text { but n.r. }\end{array}$ & $\begin{array}{l}\text { 1.5; ROI manual } \\
\text { tracing }\end{array}$ & $\begin{array}{l}\text { Enlargement in bilateral thalami, } \\
\text { striatum, caudate, and left globus } \\
\text { pallidus in comparison to DD group } \\
\text { (TBV as covariate) }\end{array}$ & $\begin{array}{l}\text { Negative correlation between RRB assessed through } \\
\text { the ADOS and right globus pallidus, right and left } \\
\text { putamen, right striatum, left thalamus (no TBV as } \\
\text { covariate) }\end{array}$ \\
\hline $\begin{array}{l}\text { Langen et al. } \\
\text { (in press) }\end{array}$ & $\begin{array}{l}49 \text { HFA } \\
37 \text { TD }\end{array}$ & $\begin{array}{l}12.1(2.3) \\
10.8(1.8)\end{array}$ & $\begin{array}{l}107,5(18,6) \\
111.9(15.0)\end{array}$ & $\begin{array}{l}\text { 1.5; ROI manual } \\
\text { tracing }\end{array}$ & $\begin{array}{l}\text { Increase in the growth rate of caudate } \\
\text { volumes (TBV as covariate) }\end{array}$ & $\begin{array}{l}\text { Positive correlation between RRB (insistence on } \\
\text { sameness) assessed through the ADI-R and } \\
\text { striatal growth }\end{array}$ \\
\hline $\begin{array}{l}\text { Wolff et al. } \\
\qquad(2013)\end{array}$ & $\begin{array}{l}30 \text { iAD } \\
\quad 41 \text { FXS } \\
16 \text { FXS + } \\
\text { AD }\end{array}$ & $\begin{aligned} & 4.7(0.7) \\
& 4.6(0.8) \\
& 4.8(0.8)\end{aligned}$ & $\begin{array}{l}70.5(32.1) \\
55.7(16.6) \\
46.3(14.1)\end{array}$ & $\begin{array}{l}\text { 1.5; semi- } \\
\text { automated } \\
\text { 3D segmentation }\end{array}$ & $\begin{array}{l}\text { Reduction in caudate volumes with } \\
\text { respect to FXS and FXS + AD (TBV as } \\
\text { covariate) }\end{array}$ & $\begin{array}{l}\text { Positive correlation between compulsive/ritual } \\
\text { behaviours and bilateral caudate volumes; } \\
\text { positive correlation between self-injurious } \\
\text { behaviour and left caudate volume (RRB assessed } \\
\text { through RBS-R) }\end{array}$ \\
\hline
\end{tabular}

AD, autistic disorder; ADI-R, Autism Diagnostic Interview-Revised; ADOS, Autism Diagnostic Observation Schedule; ASD, autism spectrum disorders; BD, bipolar disorder; BG, basal ganglia; DD, developmental delay; FXS: fragile X syndrome; FXS + AD, fragile X syndrome with autistic disorder; HFA, high-functioning autism; iAD. idiopathic autistic disorder; n.r., not reported; RBS-R, Repetitive Behaviour Scales-Revised; RRB, restricted and repetitive behaviours; TBV, total brain volume; TD, typically developing control subjects; TGMV, total grey matter volume; VBM, voxel-based morphometry; WCST, Wisconsin Card Sorting Test.

${ }^{a}$ Due to the editorials guideline of limited number of references, only the most recent MRI studies on basal ganglia volumetry in ASD were considered, starting from year 2005.

${ }^{\mathrm{b}}$ Longitudinal study. 
symptoms (Bellani et al. 2013a, b), RRB have been frequently associated with structural alterations of the basal ganglia (BG), the deep grey matter structures that include the caudate nucleus, the putamen and the globus pallidus. Several structural magnetic resonance imaging (sMRI) studies have investigated the BG volumetry in patients with ASD and its correlation with the RRB severity. The association between BG structure and RRB symptom expression has been frequently, but not always (Hardan et al. 2003), found (see Table 1) and calls for further inquiry. First, (a) since the RRB domain encompasses a broad range of symptoms, ranging from repetitive motor behaviours ('lower order' RRB) to restricted behaviours and resistance to change ('higher order' RRB), future studies should investigate if different RRB phenotypes are related to different neuroanatomical underpinnings. Second, BG alterations are present in other neuropsychiatric conditions (e.g. attention deficit-hyperactivity disorder, social anxiety or obsessive-compulsive disorders): studies that compare ASD individuals with those affected by the above-mentioned disorders could contribute to define the specific characteristics of BG involvement in ASD; and finally, the effect of potentially significant factors other than RRB (age, gender, cognitive and adaptive functioning, ASD symptom severity, comorbid psychopathology, psychotropic medications and pattern of ASD onset) on BG volumes of ASD patients has not been clearly elucidated yet: longitudinal research designs in larger sample of carefully assessed subjects could contribute to this aim.

In addition to the fact that RRB are socially inappropriate and stigmatising, they also interfere with acquisition of adaptive and social skills. Moreover, RRB affect considerably day-to-day functioning and can jeopardise optimal academic and vocational placement. Recent research has focused on methods for reducing $R R B$, by triggering a positive cascade of effects on other behaviours. Therefore, elucidating the neurobiological underpinnings of the RRB will increase our understanding of the system involved and would eventually facilitate the development of effective intervention strategies. First, since BG volumetry is related to RRB severity, future longitudinal studies should explore the potential use of BG sMRI analysis as an adjunct method for monitoring the response to intervention aimed at reducing RRB. Second, additional research is needed to identify the brain circuitry associated with different functions of RRB in individuals with ASD (e.g. self-stimulation, modulation of anxiety) in order to define tailored treatment strategies that target those pathways. Third, the integration of results from different MRI techniques (i.e. Diffusion Tensor Imaging, proton spectroscopy, resting state fMRI and functional MRI) or newer imaging analysis methods (e.g. Support Vector Machines) applied to the same subjects could enhance our knowledge on symptom-specific neurobiological underpinnings, paving the way for treatment development.

In conclusion, research into the contribution of BG abnormalities to RRB pathogenesis and pathophysiology is an emerging and challenging new area that compliments and extends the search for ASD neuroanatomical correlates, with the final aim of translating laboratory findings into clinical practice.

\section{Financial Support}

S. C. was partly supported by the Italian Ministry of Health and by Tuscany Region with the grant 'GR2010-2317873'. F. M. and S. C. were partly supported by the European Union (The MICHELANGELO Project). The other authors received no specific grant from any funding agency, commercial or not-for-profit sectors for this publication.

\section{Conflict of Interest}

None.

\section{Ethical Standard}

The authors declare that no human or animal experimentation was conducted for this work.

\section{References}

American Psychiatric Association (2013). Diagnostic and Statistical Manual of Mental Disorders (DSM-V). American Psychiatric Association: Arlington, VA. (5th edn.).

Bellani M, Calderoni S, Muratori F, Brambilla P (2013a). Brain anatomy of autism spectrum disorders I. Focus on corpus callosum. Epidemiology and Psychiatric Sciences 22, 217-221.

Bellani M, Calderoni S, Muratori F, Brambilla P (2013b). Brain anatomy of autism spectrum disorders II. Focus on amygdala. Epidemiology and Psychiatric Sciences 22, 309-312.

Estes A, Shaw DW, Sparks BF, Friedman S, Giedd JN, Dawson G, Bryan M, Dager SR (2011). Basal ganglia morphometry and repetitive behavior in young children with autism spectrum disorder. Autism Research 4, 212-220.

Hardan AY, Kilpatrick M, Keshavan MS, Minshew NJ (2003). Motor performance and anatomic magnetic resonance imaging (MRI) of the basal ganglia in autism. Journal of Child Neurology 18, 317-324.

Haznedar MM, Buchsbaum MS, Hazlett EA, LiCalzi EM, Cartwright C, Hollander E (2006). feVolumetric analysis and three-dimensional glucose metabolic mapping of the striatum and thalamus in patients with autism spectrum disorders. American Journal of Psychiatry 163, 1252-1263. 
Hollander E, Anagnostou E, Chaplin W, Esposito K, Haznedar MM, Licalzi E, Wasserman S, Soorya L, Buchsbaum M (2005). Striatal volume on magnetic resonance imaging and repetitive behaviors in autism. Biological Psychiatry 58, 226-232.

Langen M, Durston S, Staal WG, Palmen SJ, van Engeland $\mathbf{H}$ (2007). Caudate nucleus is enlarged in high-functioning medication-naive subjects with autism. Biological Psychiatry 62, 262-266.

Langen M, Schnack HG, Nederveen H, Bos D, Lahuis BE, de Jonge MV, van Engeland H, Durston S (2009). Changes in the developmental trajectories of striatum in autism. Biological Psychiatry 66, 327-333.

Langen M, Bos D, Noordermeer SD, Nederveen $H$, van Engeland H, Durston S (in press). Changes in the development of striatum are involved in repetitive behavior in autism. Biological Psychiatry.
Mandy WP, Skuse DH (2008). Research review: what is the association between the social-communication element of autism and repetitive interests, behaviours and activities? Journal of Child Psychology and Psychiatry 49, 795-808.

Rojas DC, Peterson E, Winterrowd E, Reite ML, Rogers SJ, Tregellas JR (2006). Regional gray matter volumetric changes in autism associated with social and repetitive behavior symptoms. BMC Psychiatry 6, 56-69.

Voelbel GT, Bates ME, Buckman JF, Pandina G, Hendren RL (2006). Caudate nucleus volume and cognitive performance: are they related in childhood psychopathology? Biological Psychiatry 60, 942-950.

Wolff JJ, Hazlett HC, Lightbody AA, Reiss AL, Piven J (2013). Repetitive and self-injurious behaviors: associations with caudate volume in autism and fragile $\mathrm{X}$ syndrome. Journal of Neurodevelopmental Disorders 5, 12. 